\title{
Multi-criteria decision-making tools for material selection of natural fibre composites: A review
}

\author{
M. Noryani, ${ }^{1,2}$ S. M. Sapuan, ${ }^{1 *}$, M. T. Mastura ${ }^{3}$ \\ ${ }^{1}$ Department of Mechanical and Manufacturing Engineering, Universiti Putra Malaysia, \\ 43400 UPM Serdang, Selangor, Malaysia \\ *E-mail: sapuan@upm.edu.my \\ Phone: +603-89471788; Fax: +603-86567122 \\ ${ }^{2}$ Faculty of Mechanical Engineering, Universiti Teknikal Malaysia Melaka, Hang Tuah \\ Jaya, 76100 Durian Tunggal, Melaka, Malaysia. \\ ${ }^{3}$ Faculty of Engineering Technology, Universiti Teknikal Malaysia Melaka, Hang Tuah \\ Jaya, 76100 Durian Tunggal, Melaka, Malaysia.
}

\begin{abstract}
Materials selection in manufacturing process is an important stage and should be performed in parallel with selection of manufacturing process. In automotive industry, production of green automotive component could utilize the natural sources such as plant fibres. In recent years, several multi-criteria decision-making (MCDM) techniques are suggested to choose the best materials for particular application. Materials selection tools for natural fibre composites are studied from past researchers with the summary of the advantage and disadvantages. In addition, new optimization approach in materials selection by using statistical analysis such as multiple linear regression (MLR), response surface methodology (RSM) and Taguchi method (TM) is proposed in this study. The proposed method could evaluate the criteria or attribute in materials selection precisely by analyse the relationship of the parameters, goodness of fit, correlation, analysis of variance (ANOVA), determination of coefficient and the significant criteria in to the desired goal of the design problem.
\end{abstract}

Keywords: Materials selection; natural fibre composites; multiple-criteria decisionmaking.

\section{INTRODUCTION}

Natural fibre is the natural sources that can be found in our earth and basically classified as animal, cellulose and mineral fibre as shown in Figure 1. Natural cellulose was the most command materials used in recent study. This is because environmental regulation brings paradigm shift in the composite industry and the interest in natural fibre such as jute, flax, hemp, coir and sisal. Moreover, cellulose fibre is easy in handling and process for experimental and installation purpose compare to animal and mineral fibre. Utilization of natural fibre composites (NFCs) was introduced in many applications such as automotive, construction, food packaging and medication [1-4]. Natural fibre composites are a combination of two materials which are natural fibre itself and the 
matrix. Various combinations of natural fibre and matrix have been carried out by the researcher worldwide. The fibres play as a role of reinforcement while the matrix such as thermoset, thermoplastic, polyester and polypropylene [5-9] mostly will be the main materials which the final composite can produce a good performance in some of the properties such as mechanical, physical and environmental to replace with steel base components especially in automotive industry [10-13]. Moreover, it gives an advantage as the low cost and weight, easy to process, good thermal and acoustic insulating properties [14-20].

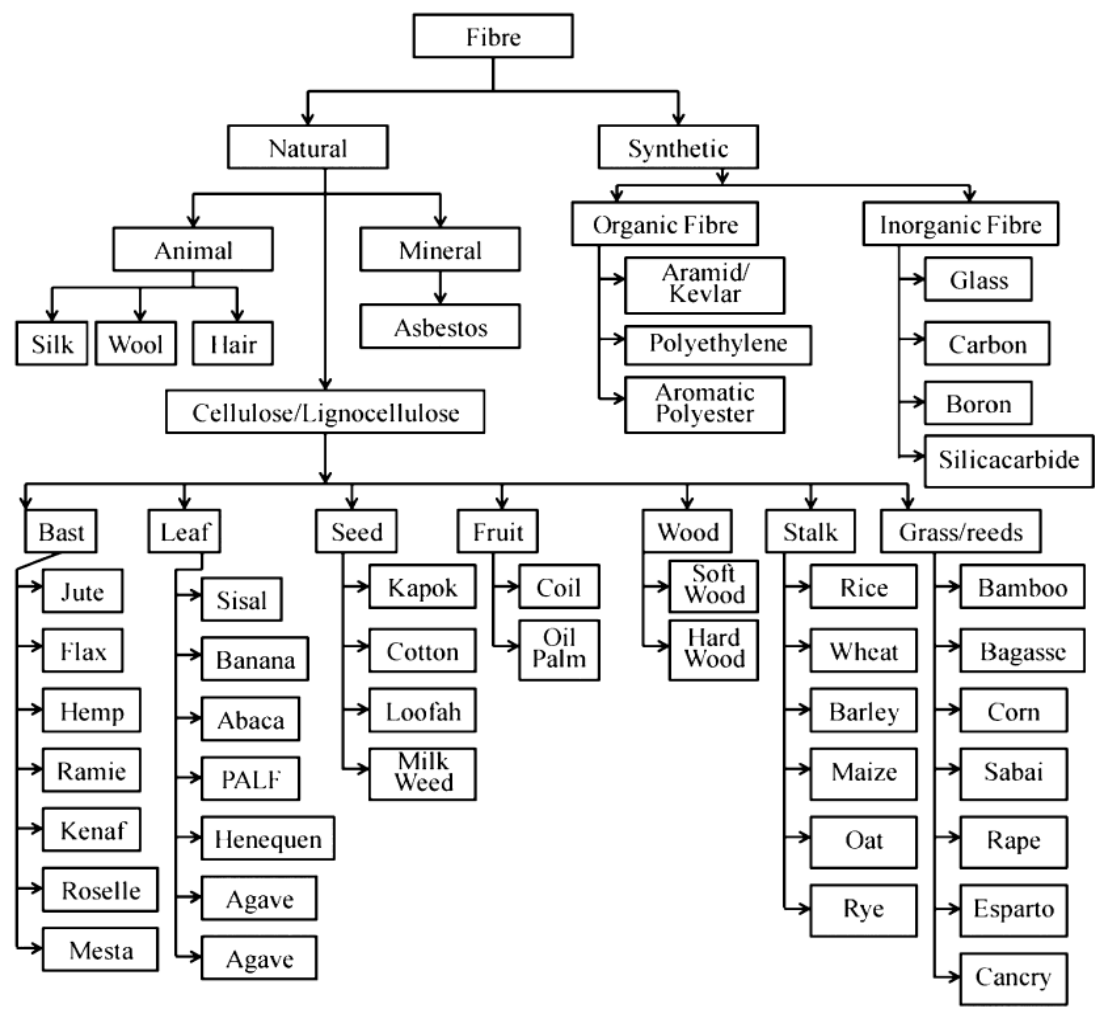

Figure 1. Classification of Natural Fibre [21]

There are several ways in combining the fibre and matrix. This would be a problem to design engineers in determine which materials is more suitable for optimizing the manufacturing process of particular design. Design engineers should select the materials carefully because the properties of the composites are not the same as metal based materials and the resultant composites' properties are depending on its constituents where some of the data are not available. In addition, the properties of the composites could be tailored by the characteristics of the constituents. The fibre orientation and number of layer of fibre also can give a different result [22]. Therefore, Multi-criteria decision-making (MCDM) are used to help design engineers to select the materials based on the several materials characteristics. There are two categories in MCDM which are multi-attribute decision-making (MADM) and multi-objective decision-making (MODM). MADM consists of evaluating and choosing process in decision making while MODM considers planning and designing [23]. Moreover, the productivity of the product in manufacturing can be maximize during the material selection process. The process must parallel with the environmental sustainability to give a benefit to the user. Therefore, in order to produce a green component with utilizing the natural source in automotive industry, customer demand and requirement 
are the important element that need to consider to meet the customer satisfaction of the product [24-26]

In this study, the materials selection of NFCs tools in MCDM is reviewed. The review includes selection of criteria or alternatives, numerical measurement of the criteria and alternatives and determination of ranking to select the final solution are examined. The advantages and disadvantages of the command tools in materials selection are presented. In fact, the potentials methodology as an alternative to the conventional method in materials selection was proposed.

\section{MATERIALS SELECTION OF NATURAL FIBRE COMPOSITES TOOLS}

In manufacturing process for automotive component, the design engineers should properly select the right materials in order to meet the standard of manufacturing process requirement. There are several tools in MCDM to select the suitable materials for automotive component design like analytical hierarchy process (AHP), analytical network process (ANP), multi-attribute utility theory (MAUT), preference selection index (PSI), technique of ranking preferences by similarity of the ideal solutions (TOPSIS), Vlse Kriterijumska Optimizacija Kompromisno Resenje (VIKOR), Elimination and Choice Expressing the Reality (ELECTRE), simple additive weighting (SAW), data envelopment analysis (DEA), Preference Ranking Organization Method for Enrichment Evaluations (PROMETHEE), Quality Function Deployment (QFD), Quality Function Deployment for the Environment (QFDE) and questionnaire.

Tramarico et al. [27] reported a trend of application of MCDM tools which was obtained from published articles in year 1990 to 2014 as shown in Figure 2. From the study, AHP was the commonly applied MCDM tool and followed by TOPSIS and ANP. The lowest application of MCDM tool that found in published articles was MAUT. A review of literature on MCDM and its application also reported by Mardani et al. [28] and discussed the data that were extracted from Web of Sciences. Most of the published articles from year 2000 to 2014 were mentioned and the application and techniques and approaches of the MCDM tools were discussed.

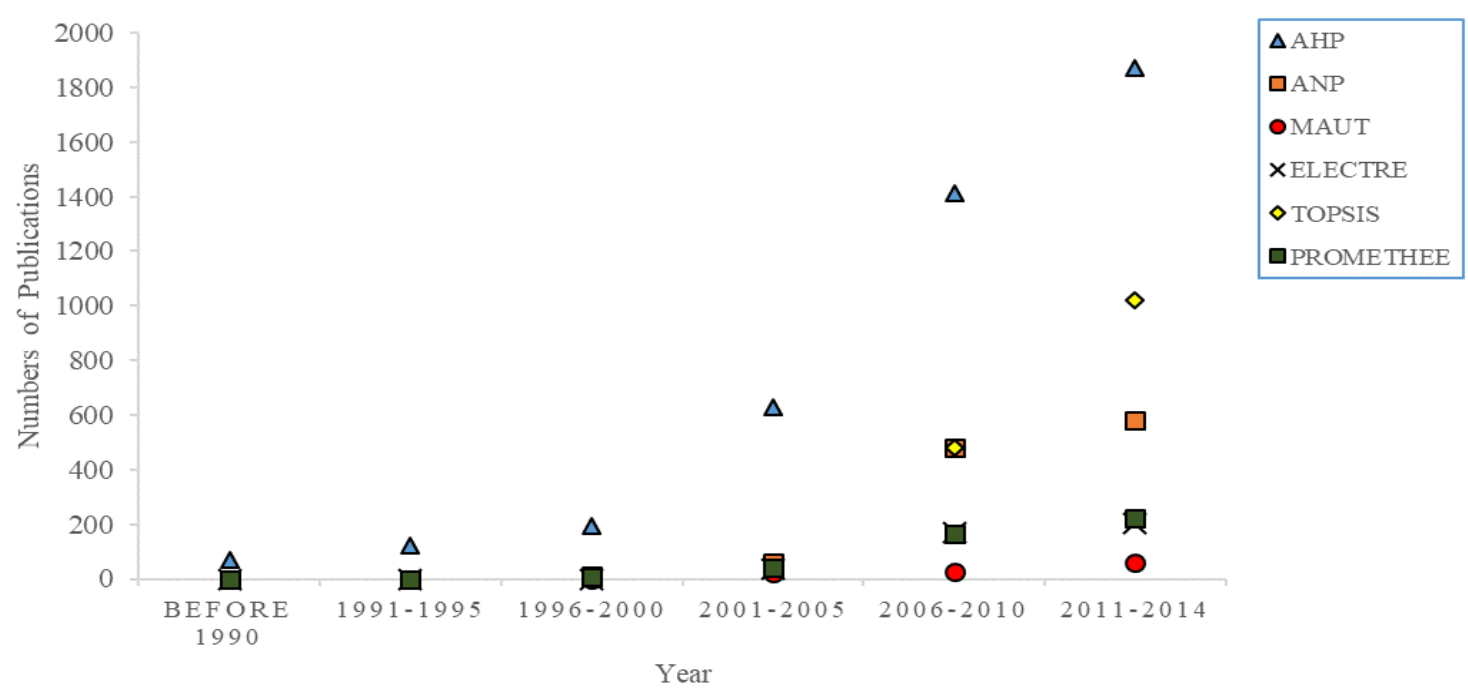

Figure 2. Multi-criteria decision-making methods used in year 1990-2014 [27] 


\section{Analytical Hierarchy Process (AHP)}

Analytic hierarchy process is a formative technique that suite to solve the mathematics and psychology complex decision in world wide application. This method was developed by Thomas L. Saaty [29] in 1970s and had been extensively study in many fields in the world. In order to select the materials based on certain criteria especially in natural fibre composites, this tool has been used to meet the product specification in a manufacturing industry. The rational and flexibility of the methodology bring the commercialization of this method in different applications like selection of conceptual design and selection of manufacturing process [25], [30-39]. Most of this study was applied in automotive component such as bumper beam, parking break lever, paddle box system, dashboard panel, anti-roll bar, gearbox and etc. AHP also can give a better result with a combination of others MCDM such as TOPSIS, ELECTRE and PROMETHEE [40-43].

\section{Analytical Network Process (ANP)}

Analytical network process is more general than AHP. This method does not require independence among elements like AHP which the decision criteria considered to be independence of one another, this rule is applied same goes to the alternatives. This tool functions to produce the super matrix by comparing between the criteria in the complete system. A study on non-metallic gears under multifunctional design requirement was done by using this tool in selecting the materials [44]. Furthermore, ANP was combined with another tool such as PROMETHEE to give a better decision on materials selection in hybrid environment [40]. Moreover, ANP was applied in electronic firm, hazardous substance management and supplier selection [45-47].

\section{Multi- Attribute Utility Theory (MAUT)}

Structural methodology is designed namely MAUT that can balance of all factors in multiple objectives. By the year 1970s, the first study that applied this method was a study on the alternative locations for a new airport in Mexico City. Malak et al. [48] proposed a new conceptual design decisions that can help the engineer to make a decision. The proposed conceptual design not required the designer to commit with a single alternative where the present information does not tolerate for rational support. National Academy of Sciences recommended this tool to investigate the safer design alternative of base case design with a new technologies [49]. By the same token, this tool was applied in machine reconfigurability models [50], supplier selection and order allocation [51].

\section{Preference Selection Index (PSI)}

Mayyas at al. [52] used PSI to develop a sustainability model within the context of an automobile structure or body-in-white. The author also used principle component analysis (PCA) to benchmark each other to get better decision in selection of the materials. Maniya and Bhatt [53] studied three difference types of materials selection problems and conclude that PSI is the most appropriate technique in materials selection. In addition, the relative importance between alternative materials selection attributes is finally defined the best solution and it is the beauty of PSI method.

\section{Technique of Ranking Preferences by Similarity of the Ideal Solutions (TOPSIS)}

TOPSIS was proposed by Tzeng and Huang [54]. This method is used based on the concept of compromise solution to define the best alternative. This solution used the 
shortest and farthest Euclidean distance from the superlative solution and the negative ideal solution respectively. A study to select the optimal hybrid bio-composite of the thermoset matrix in manufacturing the bumper beam in automotive application was conduct by using this method [55]. Mayyas et al. [56] also reported about the application of TOPSIS in order to choose automobiles' body panels and they discussed about the advantages of TOPSIS which can deal with dual quantitative and qualitative natures.

\section{Elimination and Choice Expressing the Reality (ELECTRE)}

ELECTRE I model was first develop by Roy in a year 1968 and improved by the year 1983 which is ELECTRE IV [57]. Shanian et al. [58] reported a novel application of ELECTRE III and improved Simons' procedure for group materials selection under weighting uncertainty of a thermal loaded conductor cover sheet. The best alternative material is listed to the poorest that reflect to all criteria in manufacturing process are provided using this method. The application was done on the bipolar plate using a polymer electrolyte fuel cell [59].

\section{Simple Additive Weighting (SAW)}

The characteristic of the simplicity of this method is probably the reason why SAW become the most preferred decision making tool by the researchers at the beginning of this method was introduced in a year 1954 [60]. Churchman and Ackoff [61] was the first utilize the SAW method to cope with a portfolio selection problem. SAW was applied in materials selection upon several alternatives including composites and other materials used for bipolar plate in proton exchange membrane fuel cells [62]. In addition, in Taherian's [63] review paper, he discussed the details on materials, fabrication and materials selection by using SAW. The advantages of friendly concept of this method was applied also in materials selection for piezoelectric application, polymers and photovoltaic modules [64-66].

\section{Vlse Kriterijumska Optimizacija Kompromisno Resenje (VIKOR)}

The uniqueness of this method was the optimization of complex system in determining the list of compromise, list of solution and the interval of weight stability between the initial weights. Cristobal [67] was used VIKOR in the big project by Spanish Government to select the Renewable Energy Plan to utilize the energy consumption to the global. Cristobal [67] also used the weighting process in AHP method to identify the importance level of the criteria that help the decision-makers assigned a value followed the preference. A comprehensive version of VIKOR that overcome the traditional was propose by Jahan et al. [68]. The new upgrade system can increase the exactness of materials selection finding in multiple applications. An improved version of VIKOR done by Opricovic [69] is used to overcome the main error using the original version of VIKOR by a simpler approach in difference applications.

\section{Data Envelopment Analysis (DEA)}

DEA model is a non-parametric method and does not require a complex function for variables. The capability handling a huge variable was the advantages of DEA. To solve decision model in manufacturing technology selection problem, Khouja [70] used DEA in early 1994. Sayed and Sotoudeh [71] classify DEA as an support tool for materials selection problem after performing TOPSIS and Complex Proportional Assessment (COPRAS). Moreover, he mentioned DEA not require setting the weight for the input 
and output during the decision-making process. It will be eliminating the bias problem compares to other MCDM. DEA was used to identify the best combination of vendor specification on the performance parameter to select twenty-seven industrial robots. This method widely used in supplier selection in many industry such as automotive [72], telecommunication [73] and manufacturing firm [74]. Based on article reviewed by Ho et al. [75], almost $18 \%$ article was used DEA as a tool for supplier selection. In general, the criteria studied was quality management, overall performance, efficiency, delivery process and distance of the supplier [76-78].

\section{Preference Ranking Organization Method for Enrichment Evaluations (PROMETHEE)}

The methodology using the outranking relations is implement in PROMETHEE. The alternatives for each attribute can be identify by pair-wise comparisons. Jiao et al. [79] mentioned about the advantages of PROMETHEE which doesn't involve normalization process that can minimize the error during the decision making. A study by Das and Kumar [80] was done to choose the most suitable materials of spring with desired properties for enhanced durability, low operational and manufacturing process and better performance by using PROMETHEE. Better final decision on the materials selection can be finalize by combining others MCDM such as AHP, ANP, ELECTRE and VIKOR [40], [81], [82].

More than 70 MCDM tools have been introduced for simplifying the decision procedure mentioned by Sun and Gollnick [83]. The existing tools like VIKOR, AHP, ANP, PROMTHEE, EELECT and TOPSIS would be a problem to design engineer to choose which tools would be appropriate to apply based on the given problem design. Inappropriate methods and tools cause misleading design decision. Moreover, recent researchers have emphasized the integration of MCDM tools to solve complicated decision problems. Therefore, the decision is more trustworthy and safer to apply. Whatever MCDM method is adopted to select the materials by this approach, the process of deciding the criteria, sub-criteria and their relevant weight is critical step to satisfy the requirement by the industry. Each of these tools has their own uniqueness to apply in various application. Table 1 summarize the advantages and disadvantages of these tools.

Table 1. Command tools in Materials Selection of Natural Fibre Composites

\begin{tabular}{lll}
\hline \multicolumn{1}{c}{ Tools } & \multicolumn{1}{c}{ Advantages } & \multicolumn{1}{c}{ Disadvantages } \\
\hline AHP & $\begin{array}{l}\text { Easy to use, the users can adjust } \\
\text { the relative score and tuning the height of each criterion }\end{array}$ \\
& selection process during the final alternative score. The \\
& pair-wise comparison for all judgemental of the weighting \\
& selected criteria. & was subjective problems. \\
ANP & Independence among elements & The result is not convincing \\
& is not required. The priorities because of the uncertainty. \\
& are improved from the respond \\
& can increase the level of \\
& accuracy. & \\
Takes uncertainty into account Required a bug of input and \\
and it can incorporate the preference need to be \\
preference.
\end{tabular}




\begin{tabular}{|c|c|c|}
\hline TOPSIS & $\begin{array}{l}\text { Compensatory methods that } \\
\text { allow trade-offs between } \\
\text { criteria, where a bad result in } \\
\text { one criterion can be cancelled } \\
\text { by a good result in another } \\
\text { criterion. }\end{array}$ & $\begin{array}{l}\text { Do not consider the correlation } \\
\text { of the attributes, difficult to } \\
\text { weight and keep consistency } \\
\text { of judgment. }\end{array}$ \\
\hline PSI & $\begin{array}{l}\text { Direct procedure to calculate } \\
\text { the rating score to evaluate the } \\
\text { performance of the alternative, } \\
\text { no weighting and ranking. }\end{array}$ & $\begin{array}{l}\text { The bias from the user may } \\
\text { occur because the utilization of } \\
\text { scaling scheme for qualitative } \\
\text { factors. }\end{array}$ \\
\hline ECTRE & $\begin{array}{l}\text { In the outranking step, all pairs } \\
\text { of alternative were considered. } \\
\text { It's can entertain for qualitative } \\
\text { and quantitative data. }\end{array}$ & $\begin{array}{l}\text { Additional threshold should be } \\
\text { introduced and can influence } \\
\text { the decision-making process. }\end{array}$ \\
\hline DEA & $\begin{array}{l}\text { Capable of handling multiple } \\
\text { input and output and it show } \\
\text { the efficiency of the process. }\end{array}$ & $\begin{array}{l}\text { Does not deal with imprecise } \\
\text { data, full knowledge of input } \\
\text { and output is required. }\end{array}$ \\
\hline PROMETHEE & $\begin{array}{l}\text { Outranking method and } \\
\text { consider all alternative in pair- } \\
\text { wise comparison. Simple, clear } \\
\text { and stable. }\end{array}$ & No weighting assignment. \\
\hline AW & $\begin{array}{l}\text { Simple calculation and does not } \\
\text { require complex computer } \\
\text { programs. }\end{array}$ & $\begin{array}{l}\text { The result may not logical and } \\
\text { the estimation does not } \\
\text { represent the real situation. }\end{array}$ \\
\hline JIKOR & $\begin{array}{l}\text { Comparing the degree of } \\
\text { closeness to the ideal } \\
\text { alternative and ranking the } \\
\text { alternatives with conflicting } \\
\text { factors. }\end{array}$ & $\begin{array}{l}\text { Subjective weight during the } \\
\text { process selection and the } \\
\text { process required ambiguous } \\
\text { data. }\end{array}$ \\
\hline
\end{tabular}

\section{MATERIALS SELECTIONS METHODOLOGY OF NATURAL FIBRE COMPOSITES}

The multiple characteristics of the composites can produce multiple performance of the materials and a proper procedure should be addressing to find the best output in automotive industry. Decision making is extremely intuitive when considering single criterion problem. However, in the real world, the engineer should consider the multiple criterion, goal, aspects, attributes and possible alternatives in MCDM. Most of MCDM used similar systematic evaluation steps which involving (1) determination the relevance criteria and feasible alternatives, (2) numerical measurement of the criteria and evaluation of the alternatives and (3) determining a ranking score of each alternatives [84].

\section{Determination of Criteria and Alternatives}

The capabilities and performance of the natural fibre composites that can produce a better evaluation by knowing the factors or criteria for selection [85]. A lot of features and properties should be considered in difference application. Decision maker need to 
identify the criteria or factors based on the application and product design specification (PDS) is used by the decision maker to lead the final conclusion. Al-Oqla and Sapuan [15] discuss the criteria that encourage the selection process of the materials as shown in Table 2. The most main criteria consider by the decision maker were physical, mechanical and environmental aspect [30], [86-88].

To optimize NFCs performance, three main criteria which are physical, chemical and mechanical knowledge are required. In fact, the properties of NFCs depend on the matrix and types of fibre. The environmental criteria give an advantage to produce a green product. Sapuan and Mansor [89] also discussed about the selection criteria in materials selection composites for concurrent engineering in current research.

Table 2. The criteria affect the selection of natural fibre composites materials [85]

\begin{tabular}{|c|c|c|c|c|}
\hline Physical & $\begin{array}{l}\text { Chemical } \\
\text { Biological }\end{array}$ & Mechanical & Technical & Environmental \\
\hline Density & $\begin{array}{l}\text { Chemical } \\
\text { composition } \\
\text { (cellulose, } \\
\text { lignin, etc.) }\end{array}$ & $\begin{array}{c}\text { Elastic } \\
\text { modulus }\end{array}$ & $\begin{array}{l}\text { Processing } \\
\text { energy } \\
\text { consumption }\end{array}$ & Eco-friendly \\
\hline Texture & Batch quality & Shear modulus & $\begin{array}{l}\text { Processing } \\
\text { time }\end{array}$ & $\begin{array}{l}\text { Government } \\
\text { support }\end{array}$ \\
\hline $\begin{array}{c}\text { Sound } \\
\text { absorption }\end{array}$ & $\begin{array}{c}\text { Consistency of } \\
\text { batch quality }\end{array}$ & Poisson's ratio & Processing cost & Biodegradability \\
\hline (fibre's & Availability & Yield strength & $\begin{array}{c}\text { Transferring } \\
\text { cost }\end{array}$ & $\begin{array}{l}\text { Social positive } \\
\text { view }\end{array}$ \\
\hline $\begin{array}{l}\text { diameter, } \\
\text { fibre's length, }\end{array}$ & $\begin{array}{l}\text { Resources } \\
\text { storage }\end{array}$ & $\begin{array}{l}\text { Specific yield } \\
\text { strength }\end{array}$ & Raw fibre cost & \\
\hline $\begin{array}{l}\text { length or } \\
\text { diameter ratio, } \\
\text { coefficient of } \\
\text { thermal } \\
\text { expansion. }\end{array}$ & $\begin{array}{l}\text { Planting } \\
\text { limitation }\end{array}$ & $\begin{array}{l}\text { Specific shear } \\
\text { modulus }\end{array}$ & $\begin{array}{l}\text { Cost of energy } \\
\text { input (fibre } \\
\text { separation, } \\
\text { fertilizers, } \\
\text { machines, etc) }\end{array}$ & \\
\hline $\begin{array}{l}\text { thermal } \\
\text { conductivity, } \\
\text { specific heat) }\end{array}$ & Order emission & $\begin{array}{l}\text { Elongation to } \\
\text { break }\end{array}$ & $\begin{array}{c}\text { Processing } \\
\text { knowledge and } \\
\text { time }\end{array}$ & \\
\hline & Burning rate & & $\begin{array}{c}\text { Friendly } \\
\text { processing }\end{array}$ & \\
\hline
\end{tabular}

\section{Numerical Measurement of the Criteria and Evaluation of the Alternatives}

The weighting method was applied in MCDM such as AHP, Fuzzy AHP, ANP and Fuzzy ANP where the decision maker have to give their preference weighting depend on target goal, criteria and sub-criteria [90]. The pair-wise comparison judgements were employed to analyse the importance of multiple criteria or alternatives on relative subjective scale shown in Table 3. The pair-wise comparison can be expressed as: 


$$
A=\left[\begin{array}{ccc}
a_{11} & \ldots & a_{1 n} \\
\vdots & \ddots & \vdots \\
a_{n 1} & \ldots & a_{n n}
\end{array}\right]=\left[\begin{array}{ccc}
w_{1} / w_{1} & \cdots & w_{1} / w_{n} \\
\vdots & \ddots & \vdots \\
w_{n} / w_{1} & \cdots & w_{n} / w_{n}
\end{array}\right]
$$

where $a$ an element in the judgement matrix, $i$ is the candidate materials and $j$ is the evaluation criteria. Then the normalization of eigenvector, $w$ can be calculate by using Eq. (1) [87]:

$$
w=\frac{1}{n} \sum_{j=1}^{n} \frac{a_{i j}}{\sum_{i=1}^{a} a_{i j}}, \quad i, j=1,2, \cdots, n
$$

where $w$ is the eigenvector, $a_{i j}$ is the judgement scale and $n$ is the number of criteria.

Table 3. The judgement scale of pair-wise comparison (Ariff et al., 2009)

\begin{tabular}{cl}
\hline Intensity of preference & Verbal definition \\
\hline 1 & Equally preferred \\
2 & Equally to moderate preferred \\
3 & Moderate preferred \\
4 & Moderate to strongly preferred \\
5 & Strongly preferred \\
6 & $\begin{array}{l}\text { Moderate to very strongly } \\
\text { preferred }\end{array}$ \\
7 & Very strongly preferred \\
8 & $\begin{array}{l}\text { Moderate to extremely strongly } \\
\text { preferred } \\
\end{array}$ \\
9 & Extremely strongly preferred \\
\hline
\end{tabular}

Some of the MCDM method such as TOPSIS used normalization decision matrix and weighted normalize technique to eliminate bias problem by using Eq. (2) and Eq. (3):

$$
\begin{gathered}
n_{i j}=\frac{a_{i j}}{\sqrt{\sum_{j=1}^{n} a_{i j}^{2}}} \quad i, j=1,2, \ldots, n \\
V=N_{D} \cdot W_{n \times n}=\left[\begin{array}{ccc}
V_{1 i} & \cdots & V_{1 n} \\
\vdots & \ddots & \vdots \\
V_{n 1} & \cdots & V_{n n}
\end{array}\right]
\end{gathered}
$$

where $w_{j}$ is the weight of the $i^{\text {th }}$ attribute or criterion, and the summation of the weight is equal to 1 .

Normalization technique also can use other function such as linear and non-linear, logarithmic and enhanced accuracy method rather than vector normalization as reported by Jahan and Edwards [92]. Integration on complex mathematical function such as exponential was used in PROMETHEE as explained by Peng and Xiao [40]. 
Moreover, the questionnaire is one of the tools which can benefit the decision maker to collect the information of the criteria of the materials. The questionnaire should construct base on the objectives of the study that can be analyse by using relevance statistical test such as, reliability testing, descriptive analysis and inferential analysis. This mechanism can reduce the bias of unprofessional judgement on the pairwise comparison in AHP method and can give quite consistent on the measurement [93]. However, the low respond rate of the feedback was the constraint to the researcher to choose this option.

\section{Determination of Ranking Score of Each Alternative}

The comparative weight in AHP method should be declare the consistency of the subjective perception and the accuracy by calculating the consistency ratio (CR) using Eq. (4), Eq. (5) and Table 3. The value of CR should be less than 10\%, and the judgement matrix is not accepted with more than $10 \%$ of CR.

$$
\begin{aligned}
& C I=\frac{\lambda_{\text {max }}-n}{n-1} \\
& C R=\frac{C I}{R I}
\end{aligned}
$$

where $n$ is the matrix size or criterion, $\lambda_{\max }$ is the largest eigenvalue in the judgement matrix, $C I$ is the consistency index and $R I$ is the random index of random matrix.

Table 3. Random index of random matrix [94]

\begin{tabular}{llllllllllll}
\hline$n$ & 2 & 3 & 4 & 5 & 6 & 7 & 8 & 9 & 10 & 11 & 12 \\
\hline$R I$ & 0.00 & 0.58 & 0.9 & 1.12 & 1.24 & 1.32 & 1.41 & 1.45 & 1.49 & 1.51 & 1.48 \\
\hline
\end{tabular}

Ranking order of the alternatives in TOPSIS, $C_{i}^{+}$is evaluate by calculating the ideal and non-ideal solution by using Eq. (6) until Eq. (8) [95] to choose the final alternatives.

$$
\begin{aligned}
& S_{i}^{+}=\left\{\sum_{j=1}^{n}\left(v_{i j}-v_{j}^{+}\right)^{1 / 2} ; i=1,2, \ldots, n\right\} \\
& S_{i}^{-}=\left\{\sum_{j=1}^{n}\left(v_{i j}-v_{j}^{-}\right)^{1 / 2} ; i=1,2, \ldots, n\right\} \\
& C_{i}^{+}=\frac{S_{i}^{-}}{\left(S_{i}^{+}+S_{i}^{-}\right.}, 0 \leq C_{i}^{+} \leq 1 ; i=1,2, \ldots, n
\end{aligned}
$$

The last stage process is ranking the preference of the alternatives in decreasing order.

\section{POTENTIAL TOOLS IN MATERIALS SELECTION OF NATURAL FIBRE COMPOSITES}


In a mathematical and statistical model, the connection of the independent and dependent variable is very importance to represent the powerful of the model. The prediction models, known as estimator, use the measure data as input variables in their data driven modelling. There are a few steps for each specific model to assist the decision making to achieve a goal in selecting materials. In the current study, three different data- driven model, i.e. Multiple Linear Regression (MLR), Response Surface Methodology (RSM) and Taguchi Method (TM) [96-102] are used as a tools to optimize the mechanical properties in a natural fibre composites in automotive engineering industry. In fact, the industry can produce a green automotive component due to their degradability and recyclability features.

\section{Multiple Linear Regression (MLR)}

The relationship between the independent and dependent variables can be identify by the correlation score that normally used in regression model. The least squares approach is used to fit the linear regression, however there are another method might be used such as lack of fit. Normally this regression approach derived equivalent manner throughout the process, but the definition of error, or distance from a point to the regression line is different. Basically, least squares approach is used to minimize the error from each individual point of the output. There are two category of linear regression which are Simple and Multiple Linear Regression. The simple linear regression (SLR) is occur when the set of data have one dependent variable with one regressor while multiple linear regression (MLR) is the dependent variable with more than one regressors. It is worth declaring that the MLR is the most regular form of linear regression analysis where the researcher study more than one variable that influence the output of the experiment. For each of the independent variable is associated with a value of dependent variable. It should be stressed that the MLR explores a correlation in terms of a straight line that best predicts all the individual data points containing both target and output variables. The general form of SLR and MLR model is as shown in Eq. (9) and Eq. (10):

$$
\begin{aligned}
& y_{i}=\beta_{0}+\beta_{1} x_{i}+\varepsilon_{i} \quad, i=1, \ldots, n . \\
& y_{i}=\beta_{0}+\beta_{1} x_{i}+\beta_{2} x_{i}^{2}+\varepsilon_{i} \quad, i=1, \ldots, n .
\end{aligned}
$$

where $y_{i}$ is the model output or dependent variable, $x_{i}$ are the independents input variables, $\beta_{1}, \beta_{2}, \ldots, \beta_{n}$ are partial regression coefficient, $\varepsilon_{i}$ is an error term and the subscript $i$ indexes a particular observation.

Some researcher used a linear model to check the goodness-of-fit, lack-of-fit and predictive ability of the parameterized model [103]. Furthermore, signal-to-noise ratio was the extended method from the regression to analysis the simulation and experimental data of defect carbon fibre-reinforced composite [104]. Shapiro-Wilk, Turkey and Wilcoxon test are the methods to check the normalization and determination of the significant different of data. Graupner et al. [105] found that $40 \%$ fibre loading can increase the strength of compression moulded composites while the injection moulded composites is optimize in $30 \%$ fibre loading.

This method was implemented in other industry such as civil engineering, electrical power, construction and building materials and sustainable environment [3], [106], [107]. 


\section{Response Surface Methodology (RSM)}

RSM is a combination of mathematical and statistical techniques usefull for the modeling and analysis of problems where the response of the study is effected several independent variables. The optimization of the output or response is the objective of the study for the RSM user basiccally [108].

Fundamental study and new product development require designing, formulating, developing and analyzing. RSM can be used to examine the capability of new product or study. The existing study or product also can improved efficiently by analyse the data. Industrial, Biological Science, Clinical Science, Social Science, Mechanical Engineering, Civil Engineering, Food Science and Physical are the common industry that applied RSM. The application of this method is universal and flexible around the globe. According to Hill and Hunter [109], RSM method was introduced by Box and Wilson [110] in 1951. The focus of this method at the beginning was to find the optimal response by prepared a proper sequence of designed experiments. Box and Wilson [110] suggest using a second-degree polynomial model to implement the process. The statistical model using RSM can be used as inferential statistic where the sample data is used to estimate or predict the respond, it's an approximation that help the user to guess the output on a certain condition especially during the experimental work. It can reduce the cost and time to repeat the experiment.

A study on optimization the parameters in durian skin fiber (DSF) reinforced polypropylene composites was done by using RSM [99]. The decomposition of the composites such as fiber content, fiber size and maleic anhydride polypropylene (MAPP) content are significantly affect the impact strength of PP-DSF composites. Fataneh et al. [111] was study on four factors which are temperature, hydrogen peroxide concentration, $\mathrm{pH}$ and time to optimize of dietary fiber from coffee silver skin by applied RSM.

In order to perform data modeling for responses, the researcher can expand Eq. (9) and Eq. (10) to quadratic polynomial model as shown in Eq. (11):

$$
y_{i}=\beta_{0}+\sum_{i=1}^{k} \beta_{i} x_{i}+\sum_{i=1}^{k} \beta_{i i} x_{i}^{2}+\sum \sum_{i<j} \beta_{i j} x_{i} x_{j}+\varepsilon_{i} \quad ; i=1, \ldots, n ., j=1, \ldots, m .
$$

where $y_{i}$ is the model output or dependent variable, $x_{i}$ are the independents input variables, $\beta_{1}, \beta_{2}, \ldots, \beta_{n}$ are partial regression coefficient, $\beta_{i i}$ is the interaction term, $\beta_{i j}$ is the quadratic term and $\varepsilon_{i}$ is an error term and the subscript $i$ indexes a particular observation.

A study on wear and friction properties on hybrid composite was investigate by using RSM to identify the effect of various variables such as load, sliding speed and distance. Peng et al. [96] was compare a few model by using RSM and conclude load is the most significant to the wear resistance of the hybrid composite followed by distance and speed. In addition, this method really help the researcher to optimize the study especially in composite such as in the study performed by Ashenai et al. [112] optimized the mechanical properties of polypropylene, talc and graphene. Moreover, processing condition of nonwoven flax fibre reinforced acrodur bio-composites was also optimized by this method [14]. 


\section{Taguchi Method (TM)}

Another optimization statistical method of the design of experiments in a product or study was the TM. The performance of the respond variable in the design of experiment can be achieved by using the optimum parameters suggested by the TM setting used in terms of quality and productivity of the product. The significant variable that really influences the response variable is identifying by TM. This approach is appropriate to attribute and variable data for which they are important to be analyzed. One of the process was identify the factor of an unacceptance variation, then the corrective or preventive action should be done to increase the optimization process and reduce the problem during the process of analysis.

Ghani et al. [113] mentioned that the Taguchi approach is an effective procedure and systematically precise methodology that can be applied to solved the problem. A detail study on mechanical properties of corn fibre reinforced polypropylene composite was done by using TM [114]. It was observed that the fibre of the corn can be used as filler and can increase the mechanical properties. Moreover, Kumar et al. [115] conclude that the combination of certain level of four factors on tribological analysis can produce minimum friction and wear for fibre reinforced laminates compare without fibre laminates. This study defined fibre inclusion on epoxy laminates had bigger influence on coefficient of wear and friction. These optimization method has been used in the study of fibre composite, whether natural or synthetic such as sisal, flax, kaolin, Manicaria Saccifera palm and glass [101], [116]-[118].

The optimum process combination of materials will be obtained by using the analysis of signal-to-noise ratio (SNR). The optimum combination parameter setting can produce the optimum performance by using TM [119]. Besides, the level of importance of the process materials selection of natural fibre will be determined by using statistical analysis of variance (ANOVA). This technique can reduce the number of materials, so that the best model of materiasl selection of natural fibre significantly can construct by using the Taguchi optimization method.

The potential tools in materials selection of natural fibre composites proposed in this study is illustrate in Figure 3. Three different statistical models will develop based on the parameter involved especially in mechanical properties such as tensile strength, tensile modulus, flexural strength, flexural modulus and impact strength. To select the best material in this study, statistical analysis should be performed such as correlation, coefficient of determination, analysis of variance (ANOVA) to discuss the performance for each candidate. 


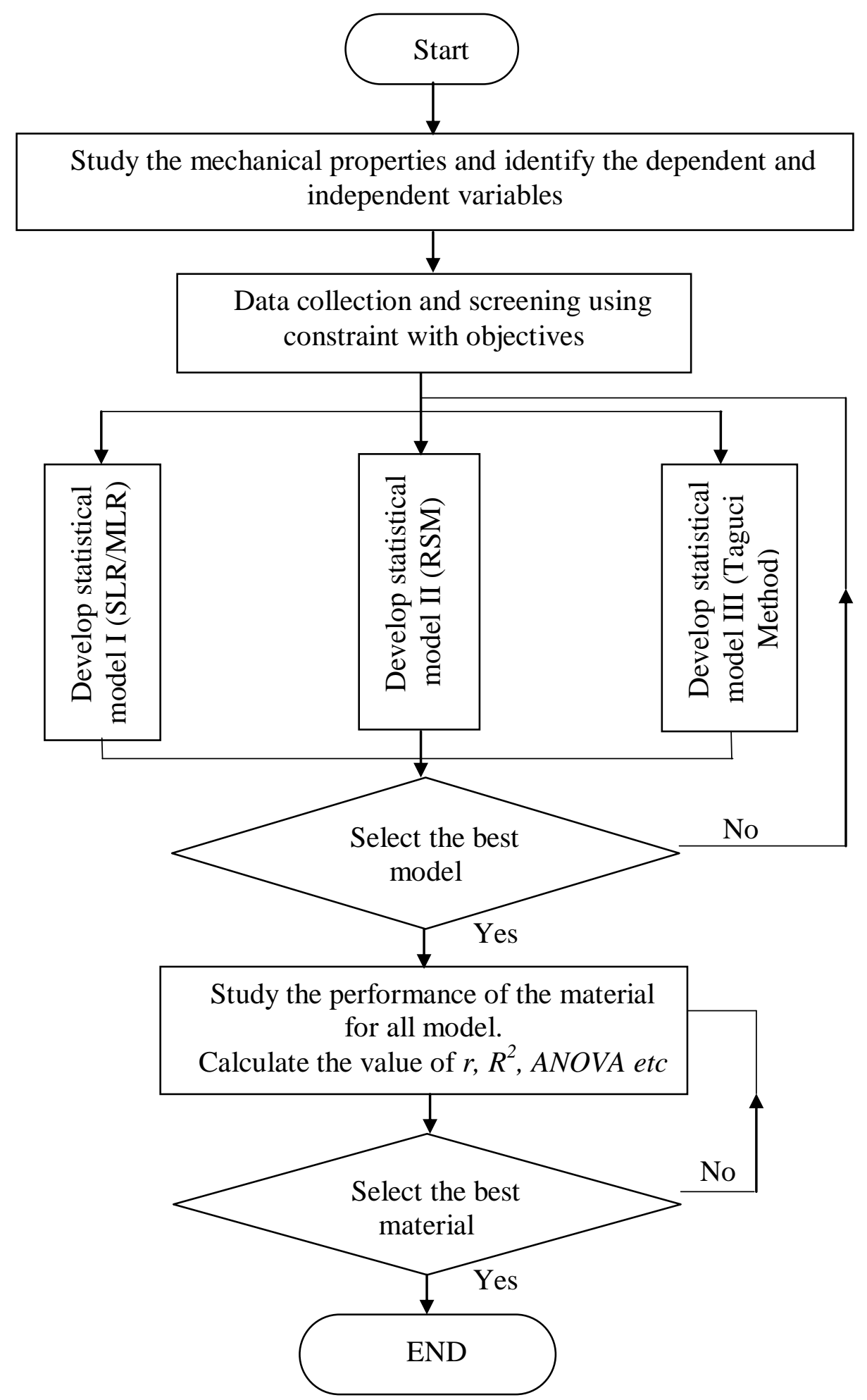

Figure 3. The framework of proposed tool in materials selection 


\section{DISCUSSION}

In this study, the review on literature in a various method in MCDM problem with explanations of the pro and cons of each method is summarized in Table 1. A combination of multiple MCDM will give different weighting, normalizing and ranking to select the final output material [120]. The disadvantages of the weighting process of the criteria in AHP and ANP is a subjective problem that can issue biasness to the final decision. There is no theoretical support or defend about the judgement preference for the criteria and alternative in MCDM. Furthermore, some of the methods neglect the uncertainty criteria such as ANP. Some practice combined the criteria for a better evaluation [85], [121]. The criteria or alternative is involve both qualitative and quantitative measurement, Sabaei et al. [122] mentioned about the weakness of the PROMOTHEE that cannot deal with qualitative data because there is no weighting process. In addition, the process in PSI also can create the bias because of utilization of scaling scheme for qualitative factors. The problem also occur when there are dependency between the criteria and sub-criteria in the complex hierarchy that will influence the final decision [31]. The simple calculation in SAW can discharge nonlogical and does not represent the real situation on decision making.

In introducing new optimization approach such as Regression, RSM and TM in materials selection of NFRPCs will improve the selection process to optimal material that satisfied PDS, customer satisfaction and needed, industry regulation and compete commercially. These optimization methods have greatest advantage such as saving effort in conduction experiment, saving experimental time, reducing cost and discovering significant factors or attributes quickly can improve the decision making. In addition, the optimal process parameters (material) and significant factors or attributes of natural fibre composites will further be determined by using the aid of statistical software such as Minitab and SPSS. The conventional method such as AHP, ANP, and TOPSIS can be used as a reference to build new statistical model in three separate way. From three difference methods in conducting the statistical model of the materials selection will beneficially to improve the final decision making by consider quantitative and qualitative measurement of the criteria compare to the subjective judgement in MCDM. The proposed method also can give an advantage for a better prediction for example the mechanical properties in a composite such as tensile strength can be predicted with the input of a certain variable to the model constructed. In addition, multicollinearity problem can be defining by calculating the variance inflation factors (VIF) to clarify the relationship among the criteria and sub-criteria that neglected by most of MCDM methods.

\section{CONCLUSIONS}

The present new approach optimization of materials selection on natural fibre composites is highly flexible. Hence, by optimal analysis of the model by using statistical analysis in three difference statistical model can increase the trustworthy and confident to the user such as design engineer in manufacturing process. Therefore, future work can be considered for the classification of current MCDM method in order to get comprehensive materials selection process for the propose methods. As conclusion, the proposed statistical modelling discussed in this paper can be used to 
develop the model selection of the materials by using the statistical approaches. The results can be considered as an alternative to the conventional method.

\section{ACKNOWLEDGEMENTS}

The authors would like to thank Universiti Putra Malaysia for the opportunity doing this study as well as Universiti Teknikal Malaysia Melaka for providing the scholarship award to the principal author in this project.

\section{REFERENCES}

[1] Macuvele D. L. P., Nones J., Matsinhe J., Lima M., Soares C., Fiori M. and Riella H.. Advances in ultra high molecular weight polyethylene/hydroxyapatite composites for biomedical applications: A brief review. Materials Science and Engineering C. 2017.

[2] Sharabi M., Benayahu D., Benayahu Y., Isaacs J. and Haj-Ali R.. Laminated collagen-fiber bio-composites for soft-tissue bio-mimetics. Composites Science and Technology. 2015;117:268-76.

[3] Chithra S., Kumar S. R. R. S., Chinnaraju K. and Alfin Ashmita F.. A comparative study on the compressive strength prediction models for High Performance Concrete containing nano silica and copper slag using regression analysis and Artificial Neural Networks. Construction and Building Materials. 2016;114:528-35.

[4] Mansor M. R., Hambali A., Azaman M. D., Sapuan S. M., Zainudin E. S. and Nuraini A. A.. Material selection of thermoplastic matrix for hybrid natural fiber/ glass fiber polymer composites using analytic hierarchy process method. International Symposium on the Analytic Hierarchy Process. 2013.

[5] Loh X. H., Daud M. A. M. and Selamat M. Z.. Mechanical properties of kenaf/polypropylene composite: An investigation. Journal of Mechanical Engineering and Sciences. 2016;10(2):2098-2110.

[6] Islam M. R. and BegM. D. H.. Effects of reinforcing arrangement of kenaf fibres into unsaturated polyester for improved properties. Journal of Mechanical Engineering and Sciences. 2016;10(2):2020-30.

[7] Lee C. H., Sapuan S. M., Lee J. H. and Hassan M. R.. Mechanical properties of kenaf fibre reinforced floreon biocomposites with magnesium hydroxide filler. Journal of Mechanical Engineering and Sciences.2016;10(3):2234-48.

[8] Jumaidin R., Sapuan S. M., Jawaid M., Ishak M. R. and Sahari J.. Effect of seaweed on physical properties of thermoplastic sugar palm starch/agar composites. Journal of Mechanical Engineering and Sciences.2016;10(3):221425.

[9] AL-Oqla F. M., Sapuan S. M., Ishak M. R. and Nuraini A. A.. A Model for Evaluating and Determining the Most Appropriate Polymer Matrix Type for Natural Fiber Composites. International Journal of Polymer Analysis and 
Characterization.2015;20(3):191-205.

[10] Bartosz T. W., Fan M. and Hui D.. Compressive behaviour of natural fibre composite. Composites Part B. 2014;67:183-91.

[11] Ramesh M., Palanikumar K. and Reddy K. H.. Mechanical Property Evaluation of Sisal-Jute-Glass Fiber Reinforced Polyester Composites. Composites Part B. 2012;48:1-9.

[12] Yahaya R., Sapuan S. M., Jawaid M., Leman Z. and Zainudin E. S.. Effect of layering sequence and chemical treatment on the mechanical properties of woven kenaf-aramid hybrid laminated composites. Materials and Design. 2015;67:17379 .

[13] Fairuz A. M., Sapuan S. M., Zainudin E. S. and Jaafar C. A.. Effect of filler loading on mechanical properties of pultruded kenaf fibre reinforced vinyl ester composites. Journal of Mechanical Engineering and Sciences. 2016;10(1):193142.

[14] Rasyid M. F. A., Salim M. S., Akil H. M. and Ishak Z. A. M.. Optimization of Processing Conditions Via Response Surface Methodology (RSM) of Nonwoven Flax Fibre Reinforced Acrodur Biocomposites. Procedia Chemistry. 2016;19:469-76.

[15] Al-Oqla F. M. and Sapuan S. M.. Natural fiber reinforced polymer composites in industrial applications: Feasibility of date palm fibers for sustainable automotive industry. Journal of Cleaner Production. 2014;66:347-54.

[16] Razali N., Salit S., Jawaid M., Ishak M. R. and Lazim Y.. A Study on Chemical Composition, Physical, Tensile, Morphological, and Thermal Properties of Roselle Fibre:Effect of Fibre Maturity. BioResources. 2015;10(1):1803-24.

[17] Mustafa A., Abdollah M. F., Shuhimi F. F., Ismail N., Amiruddin H. and Umehara N.. Selection and verification of kenaf fibres as an alternative friction material using Weighted Decision Matrix method. Materials and Design. 2015;67:577-82.

[18] Bahrani F., Safari A., Vojdani M. and Karampoor G.. Comparison of Hardness and Surface Roughness of Two Denture bases Polymerized by Different Methods. World Journal Od Dentistry. 2012;3(2):171-76.

[19] Tezara C., Siregar J. P., Lim H. Y., Fauzi F. A., Yazdi M. H., Moey L. K. and Lim J. W.. Factors that affect the mechanical properties of kenaf fiber reinforced polymer: A review. Journal of Mechanical Engineering and Sciences. 2016;10(2):2159-75.

[20] Al-Oqla F. M. and Salit M. S.. Natural Fiber Composites in Materials Selection for Natural Fiber Composites, 1st ed., Cambridge, USA: Woodhead Publishing, Elsevier. 2017:23-45.

[21] Al-Oqla F. M., Sapuan S. M., Anwer T., Jawaid M. and Hoque M. E.. Natural fiber reinforced conductive polymer composites as functional materials: A review. Synthetic Metals. 2015;206:42-54.

[22] Ismail A. E. and Aziz M. A. C. A.. Tensile strength of woven yarn kenaf fiber reinforced polyester composites. Journal of Mechanical Engineering and Sciences. 2015;9:1695-1704.

[23] Tzeng G. H and Huang J. J.. Multiple Attribute Decision Making Methods and Applications. 2011.

[24] Mastura M. T., Sapuan S. M. and Mansor M. R.. A framework for prioritizing customer requirements in product design: Incorporation of FAHP with AHP. Journal of Mechanical Engineering and Sciences. 2015;9:1655-70. 
[25] Das D., Bhattacharya S. and Sarkar B.. Decision-based design-driven material selection: A normative-prescriptive approach for simultaneous selection of material and geometric variables in gear design. Materials and Design. 2016;92:787-93.

[26] Al-Oqla F. M. and Salit M. S.. Materials Selection in Materials Selection for Natural Fiber Composites, 1st ed., Cambridge, USA: Woodhead Publishing, Elsevier. 2017:49-68.

[27] Tramarico C. L., Mizuno D., Antonio V., Salomon P., Augusto F. and Marins S.. Analytic Hierarchy Process and Supply Chain Management: a bibliometric study. 2015;55:441-50.

[28] Mardani A., Jusoh A., Nor K., Khalifah Z. and Valipour A.. Multiple criteria decision-making techniques and their applications - a review of the literature from 2000 to 2014. Economic Research Ekonomska Istrazivanja. 2015;28(1):516-71.

[29] Saaty T. L.. Decision making with the Analytic Hierarchy Process. International Journal of Services Science. 2008;1(1):83-98.

[30] Hambali A., Sapuan S. M., Ismail N. and Nukman Y.. Material selection of polymeric composite automotive bumper beam using analytical hierarchy process. Journal Cent South University Technology. 2010;17:244-56.

[31] Mayyas A., Shen Q., Mayyas A., Abdelhamid M., Shan D., Qattawi A. and Omar M.. Using Quality Function Deployment and Analytical Hierarchy Process for material selection of Body-In-White. Materials and Design. 2011;32(5):2771-82.

[32] Mansor M. R., Sapuan S. M., Zainudin E. S., Nuraini A. A. and Hambali A.. Hybrid natural and glass fibers reinforced polymer composites material selection using Analytical Hierarchy Process for automotive brake lever design. Materials and Design. 2013;51:484-92.

[33] Mansor M. R., Sapuan S. M., Zainudin E. S., Nuraini A. A. and Hambali A.. Conceptual design of kenaf fiber polymer composite automotive parking brake lever using integrated TRIZ - Morphological Chart - Analytic Hierarchy Process method. Materials and Design. 2014;54:473-82.

[34] Sapuan S. M. A conceptual design of the concurrent engineering design system for polymeric-based composite automotive pedals. American Journal of Applied Sciences. 2005;2(2):514-525.

[35] Hambali A., Sapuan S. M., Rahim A. S., Ismail N. and Nukman Y.. Concurrent Decisions on Design Concept and Material Using Analytical Hierarchy Process at the Conceptual Design Stage. Concurrent Engineering: Research and Applications. 2011;19(2):111-21.

[36] Mastura M. T., Sapuan S. M., Mansor M. R. and Nuraini A. A.. Conceptual design of a natural fibre-reinforced composite automotive anti-roll bar using a hybrid approach. International Journal of Advanced Manufacturing Technology. 2017;9(5):2031-48.

[37] Hambali A., Sapuan S. M., Ismail N. and Nukman Y.. Composite manufacturing process selection using analytical hierarchy process. International Journal of Mechanical and Materials Engineering. 2009;4(1):49-61.

[38] F. M. Al-Oqla, S. M. Sapuan, M. R. Ishak, and A. A. Nuraini, "A decisionmaking model for selecting the most appropriate natural fiber - Polypropylenebased composites for automotive applications," J. Compos. Mater., vol. 50, no. 4, pp. 543-556, 2015.

[39] Al-Oqla F. M. and Salit M. S.. Materials Selection of Natural Fiber Composites 
using the Analytical Hierarchy Process in Materials Selection for Natural Fiber Composites, 1st ed., Cambridge, USA: Woodhead Publishing, Elsevier. 2017:169-234.

[40] Peng A. H. and Xiao X. M.. Material selection using PROMETHEE combined with analytic network process under hybrid environment. Materials and Design. 2013;47:643-52.

[41] Yousefpour M. and Rahimi A.. Characterization and selection of optimal parameters to achieve the best tribological performance of the electrodeposited Cr nanocomposite coating. Materials and Design. 2014;54:382-89.

[42] Kuo C. J., Lin C., Hsu M. and Li M.. Evaluation of intelligent green building policies in Taiwan - Using fuzzy analytic hierarchical process and fuzzy transformation matrix. Energy and Building. 2017;139:146-59.

[43] Al-Oqla F. M., Sapuan S. M., Ishak M. R. and Nuraini A. A.. Decision making model for optimal reinforcement condition of natural fiber composites. Fibers and Polymers. 2015;16(1):153-63.

[44] Milani A. S., Shanian A., Lynam C. and Scarinci T.. An application of the analytic network process in multiple criteria material selection. Materials and Design. 2013;44:622-32.

[45] Gencer C. and Gürpinar D.. Analytic network process in supplier selection: A case study in an electronic firm. Applied Mathematical Modelling. 2007;31(11):2475-86.

[46] Hsu C.-W. and Hu A. H.. Applying hazardous substance management to supplier selection using analytic network process. Journal of Cleaner Production. 2009;17(2):255-64.

[47] Liao C.-N. and Kao H.-P.. Supplier selection model using Taguchi loss function, analytical hierarchy process and multi-choice goal programming. Computers \& Industrial Engineering. 2010;58(4):571-77.

[48] Malak R. J., Aughenbaugh J. M. and Paredis C. J. J.. Multi-attribute utility analysis in set-based conceptual design. Computer-Aided Design. 2009;41(3):214-27.

[49] Ogle R. A., Dee S. J. and Cox B. L.. Resolving inherently safer design conflicts with decision analysis and multi-attribute utility theory. Process Safety and Environmental Protection. 2015;97:61-69.

[50] Hasan F., Jain P. K. and Kumar D.. Machine reconfigurability models using multi-attribute utility theory and power function approximation. Procedia Engineering. 2013;64:1354-63.

[51] Sanayei A., Farid S. M., Abdi M. R. and Mohaghar A.. An integrated group decision-making process for supplier selection and order allocation using multiattribute utility theory and linear programming. Journal of the Franklin Institute. 2008;345(7):731-47.

[52] Mayyas A. T., Qattawi A., Mayyas A. R. and Omar M.. Quanti fi able measures of sustainability: a case study of materials selection for eco-lightweight autobodies. Journal of Cleaner Production. 2013;40:177-89.

[53] Maniya K. and Bhatt M. G.. A selection of material using a novel type decisionmaking method: Preference selection index method. Materials and Design. 2010;31(4):1785-89.

[54] Tzeng G. H. and Huang J. J.. TOPSIS and VIKOR in Multiple Attribute Decision Making Methods and Applications, United State of America: CRC Press. 2011;69-80. 
[55] Mansor M. R., Sapuan S. M., Hambali A., Zainudin E. S. and Nuraini A. A.. Materials Selection of Hybrid Bio-Composites Thermoset Matrix for Automotive Bumper Beam Application using Topsis Method. Advances in Environmental Biology. 2014;8(8):3138-42.

[56] Mayyas A., Omar M. A., Hayajneh M. T., Mayyas A., Omar M. A. and Hayajneh M. T.. Eco-material selection using fuzzy TOPSIS method. International Journal of Sustainable Engineering. 2016.

[57] Tzeng G. H. and Huang J. J.. ELECTRE Method in Multiple attributes decision making methods and applications, United State of America: CRC Press. 2011;81-93.

[58] Shanian A., Milani A. S., Carson C. and Abeyaratne R. C.. A new application of ELECTRE III and revised Simos' procedure for group material selection under weighting uncertainty. Knowledge-Based Systems. 2008;21(7):709-20.

[59] Shanian A. and Savadogo O.. A non-compensatory compromised solution for material selection of bipolar plates for polymer electrolyte membrane fuel cell (PEMFC) using ELECTRE IV. Electrochimica Acta. 2006;51(25):5307-15.

[60] Spurgeon V. J. and Spurgeon P. C.. The relative importance of potential outcomes of occupational guidance: An assessment by occupational guidance officers. Journal of Occupational Psychology. 1982;55:191-95.

[61] Churchman C. W. and Ackoff R. L.. An approximate measure of value. Journal of Operations Research Society of America. 1954;2(1):172-87.

[62] Reza Taherian M. N.. Performance and material selection of nanocomposite bipolar plate in proton exchange membrane fuel cells. International Journal of Energy Research. 2012;33(4):23-40.

[63] Taherian R.. A review of composite and metallic bipolar plates in proton exchange membrane fuel cell: Materials, fabrication, and material selection. Journal of Power Sources. 2014;265:370-90.

[64] Vega J. F., Otegui J., Exposito M. T., Lopez M., Martin C. and Martinez J.. Structure and physical properties of polyethylenes obtained from dual catalysis process. Polymer Bulletin. 2008;60(2-3):331-42.

[65] Chauhan A., Vaish R. and Bowen C.. Piezoelectric material selection for ultrasonic transducer and actuator applications. Proceedings of the Institution of Mechanical Engineers, Part L: Journal of Materials: Design and Applications. 2013;229(1):3-12.

[66] Demian G., Grecu L. and Demian M.. Multi-criteria methods for selection of encapsulation materials for photovoltaic cells. Environmental Engineering and Management Journal. 2016;15(10):2337-46.

[67] Cristóbal J. R. S.. Multi-criteria decision-making in the selection of a renewable energy project in spain: The Vikor method. Renewable Energy. 2011;36:498502.

[68] Jahan A., Mustapha F., Ismail M. Y., Sapuan S. M. and Bahraminasab M.. A comprehensive VIKOR method for material selection. Materials and Design. 2011;32(3):1215-21.

[69] Opricovic S.. Fuzzy VIKOR with an application to water resources planning. Expert Systems with Applications. 2011;38(10):12983-90.

[70] Khouja M.. The use of data envelopment analysis for technology selection. Computers Ind. Engineering. 1995;28(1):123-32.

[71] Mousavi-Nasab S. H. and Sotoudeh-Anvai A.. A comprehensive MCDM-based approach using TOPSIS, COPRAS and DEA as an auxiliary tool for material 
selection problems. Materials and Design. 2017.

[72] Mathiyazhagan K., Sudhakar S. and Bhalotia A.. Modeling the criteria for selection of suppliers towards green aspect : a case in Indian automobile industry. OPSEARCH. 2017.

[73] Narasimhan R., Talluri S. and Mendez D.. Supplier Evaluation and Rationalization via Data Envelopment Analysis : An Empirical Examination. The Journal of Supply Chain Management. 2001;28-37.

[74] Liu J., Ding F. and Lall V.. Using data envelopment analysis to compare suppliers for supplier selection and performance improvement. Supply Chain Management: An International Journal. 2000;5(3):143-50.

[75] Ho W., Xu X. and Dey P. K.. Multi-criteria decision making approaches for supplier evaluation and selection: A literature review. European Journal of Operational Research. 2010;202(1):16-24.

[76] Wu D.. Supplier selection : A hybrid model using DEA, decision tree and neural network. Expert Systems With Applications. 2009;36(5):9105-12.

[77] Ghorabaee M. K., Amiri M., Kazimieras E. and Antucheviciene J.. Supplier evaluation and selection in fuzzy environments : a review of MADM approaches. Economic Research-Ekonomska Istraživanja. 2017;9664:1-46.

[78] Fallahpour A., Amindoust A., Antuchevičienè J. and Yazdani M.. Nonlinear genetic-based model for supplier selection: a comparative study. Technological and Economic Development of Economy. 2016;4913.

[79] Jiao Q., Lan Y., Guan Z. and Z. Li. A New Material Selection Approach Using PROMETHEE Method. International Conference on Electronic \& Mechanical Engineering and Information Technology. 2011;2950-54.

[80] Das A. and Kumar A.. Selection of Spring Material Using PROMETHEE Method. Journal of Mechanical and Civil Engineering. 2015;12(5):82-91.

[81] Chothani H. G., Kuchhadiya B. B. and Solanki J. R.. Selection of Material for Hacksaw Blade using AHP-PROMETHEE Approach. International Journal of Innovative Research in Advanced Engineering. 2015;2(1):26-30.

[82] Patra A. and Dan P. K.. Selection of facility layout design using PROMETHEE and VIKOR. International Journal of Mechanical and Production Engineering. 2013;1(2):15-22.

[83] Sun X. and Gollnick V.. Intelligent Multicriteria Decision Support System for Systems Design. Journal of Aircraft. 2014;51(1):1-11.

[84] Yang S. S., Nasr N., Ong S. K. and Nee A. Y. C.. Designing automotive products for remanufacturing from material selection perspective. Journal of Cleaner Production. 2015;1-10.

[85] Al-Oqla F. M., Salit M. S., Ishak M. R. and Aziz N. A.. Selecting natural fibers for bio-based materials with conflicting criteria. American Journal of Applied Sciences. 2015;12(1):64-71.

[86] Davoodi M. M., Sapuan S. M., Ahmad D., Aidy A., Khalina A. and Jonoobi M.. Concept selection of car bumper beam with developed hybrid bio-composite material. Materials and Design. 2011;32(10):4857-65.

[87] Mansor M. R., Sapuan S. M., Zainudin E. S., Nuraini A. A. and Hambali A.. Application of Integrated AHP-TOPSIS Method in Hybrid Natural Fiber Composites Materials Selection for Automotive Parking Brake Lever Component," Aust. J. Basic Appl. Sci., vol. 8, pp. 431-439, 2014.

[88] Mastura M. T., Sapuan S. M., Mansor M. R. and Nuraini A. A.. Environmentally conscious hybrid bio-composite material selection for automotive anti-roll bar. 
International Journal of Advanced Manufacturing Technology. 2017;89(58):2203-19.

[89] Sapuan S. M. and Mansor M. R.. Concurrent engineering approach in the development of composite products: A review. Materials and Design. 2014;58:161-67.

[90] Jiang Z., Zhang H. and Sutherland J. W.. Development of multi-criteria decision making model for remanufacturing technology portfolio selection. Journal of Cleaner Production. 2011;19(17-18):1939-45.

[91] Hambali A., Sapuan S. M., Ismail N. and Nukman Y.. Use of analytical hierarchy process (AHP) for selecting the best design concept. Journal Teknologi. 2009;49:1-18.

[92] Jahan A. and Edwards K. L.. A state-of-the-art survey on the influence of normalization techniques in ranking: Improving the materials selection process in engineering design. Materials and Design. 2015;65:335-42.

[93] Al-widyan M. I. and Al-oqla F. M.. Utilization of Supplementary Energy Sources for Cooling In Hot Arid Regions via Decision-Making Model. International Journal of Engineering Research and Applications. 2011;1(4):1610-22.

[94] Raharjo H. and Endah D.. Evaluating Relationship of Consistency Ratio and Number of Alternatives on Rank Reversal in the AHP Evaluating Relationship of Consistency Ratio and Number of Alternatives on. Quality Engineering. 2006;18(1):39-46.

[95] Emre F., Genç S., Kurt M. and Akay D.. A multi-criteria intuitionistic fuzzy group desicion making for suplier selection with TOPSIS method. Expert System with Applications. 2009;36:11363-68.

[96] Peng B., Akil H., Ghaddafy M., Khan A. and Md Nasir R.. Comparative study of wear performance of particulate and fiber-reinforced nano- $\mathrm{ZnO} /$ ultra-high molecular weight polyethylene hybrid composites using response surface methodology. Materials and Design. 2014;63:805-19.

[97] Alavudeen A., Rajini N., Karthikeyan S., Thiruchitrambalam M. and Venkateshwaren N.. Mechanical properties of banana / kenaf fiber-reinforced hybrid polyester composites: Effect of woven fabric and random orientation. Materials and Design. 2015;66:246-57.

[98] Hojo T., Zhilan X. U., Yang Y. and Hamada H.. Tensile properties of bamboo, jute and kenaf mat-reinforced composite. Energy Procedia. 2014;56:72-79.

[99] Aimi N. N., Anuar H., Manshor M. R., Nazri W. B. W. and Sapuan S. M.. Optimizing the parameters in durian skin fiber reinforced polypropylene composites by response surface methodology. Industrial Crops and Products. 2014;54:291-95.

[100] Mehboob H. and Chang S.-H.. Optimal design of a functionally graded biodegradable composite bone plate by using the Taguchi method and finite element analysis. Composites Structures. 2015;119:166-73.

[101] Porras A., Maranon A. and Ashcroft I. A.. Optimal tensile properties of a Manicaria-based biocomposite by the Taguchi method. Composite Structures. 2016;140:692-701.

[102] Sreenivasulu R.. Optimization of surface roughness and delamination damage of GFRP composite material in end milling using taguchi design method and artificial neural network. Procedia Engineering. 2013;64:785-94.

[103] Newton P. F.. Quantifying size-dependent developmental trajectories of commercial-relevant fibre attributes within maturing black spruce plantations 
employing hierarchical linear models. Forest Ecology and Management. 2016;381:1-16.

[104] Lopez F., Ibarra-Castanedo C., De Paulo Nicolau V. and Maldague X.. Optimization of pulsed thermography inspection by partial least-squares regression. NDT and E International. 2014;66:128-38.

[105] Graupner N., Ziegmann G., Fabian W. and Beckmann J. M.. Procedural influences on compression and injection moulded cellulose fibre-reinforced polylactide (PLA) composites: Influence of fibre loading, fibre length, fibre orientation and voids. Composites Part A: Applied Science and Manufacturing. 2016;81:158-71.

[106] Khademi F., Jamal S. M., Deshpande N. and Londhe S.. Predicting strength of recycled aggregate concrete using Artificial Neural Network, Adaptive NeuroFuzzy Inference System and Multiple Linear Regression. International Journal of Sustainable Built Environment. 2016;5(2):355-69.

[107] Xu X., Yan Z. and Carlo Q.. Electrical Power and Energy Systems Probabilistic load flow calculation with quasi-Monte Carlo and multiple linear regression. Electrical Power and Energy Systems. 2017;88:1-12.

[108] Montgomery D. C. Design and Analysis of Experiments, 6th ed. United States of Amarica: John Wiley \& Sons Inc, 2005.

[109] Hill W. J. and Hunter W. G.. A Review of Response Surface Methodology: A Literature Survey. Technometrics. 1966;8(4):571-90.

[110] Box G. E. P. and Wilson K. B.. On the Experimental Attainment of Optimum Conditions. Journal of the Royal Statistical Society Series B. 1951;13(1):1-45.

[111] Fataneh Behrouzian S. M. A. R., Asad Mohammad Amini, Ali Alghooneh. Characterization of dietary fiber from coffee silverskin: An optimization study using response surface methodology. Bioactive Carbohydrates and Dietary Fibre. 2016;8:58-64.

[112] Ashenai F., Ghasemi I., Menbari S. and Ayaz M.. Optimization of mechanical properties of polypropylene / talc / graphene composites using response surface methodology. Polymer Testing. 2016;53:283-92.

[113] Ghani J. A., Choudhury I. A. and Hassan H. H.. Application of Taguchi method in the optimization of end milling parameters. Journal of Materials Proceeding Technology. 2004;145:84-92.

[114] Kumar N. R., Rao C. R., Srikant P. and Rao B. R.. Mechanical properties of corn fiber reinforced polypropylene composites using Taguchi method. Materials Today Proceedings. 2015;2(4-5):3084-92.

[115] Kumar M. S. S., Sundara N. M., Sampath P. S. and Vivek U.. Tribological analysis of nano clay / epoxy / glass fiber by using Taguchi' s technique. Journal of Materials \& Design. 2015;70:1-9.

[116] Kc B., Faruk O., Agnelli J. A. M., Leao A. L., Tjong J. and Sain M.. Sisal-glass fiber hybrid biocomposite: Optimization of injection molding parameters using Taguchi method for reducing shrinkage. Composites Part A: Applied Science and Manufacturing. 2016;83:152-59.

[117] Prakash A., Sarkhel G. and Kumar K.. Strength Optimization for Kaolin Reinforced Epoxy Composite Using Taguchi Method. Materials Today Proceedings. 2015;2(4-5):2380-88.

[118] Abdul Nasir A. A., Azmi A. I. and Khalil A. N. M.. Measurement and optimisation of residual tensile strength and delamination damage of drilled flax fibre reinforced composites. Measurement: Journal of the International 
Measurement Confederation. 2015;75:298-307.

[119] Jamaluddin H., Ghani J. A., Deros B. M., Rahman M. N. A. and Ramli R.. Quality improvement using Taguchi method in shot blasting process. Journal of Mechanical Engineering and Sciences. 2016;10(2):2200-13.

[120] Jahan A., Ismail Y., Shuib S., Norfazidah D. and Edwards K. L.. An aggregation technique for optimal decision-making in materials selection. Materials and Design. 2011;32:4918-24.

[121] Al-Oqla F. M., Salit M. S., Ishak M. R. and Aziz N. A.. Combined multi-criteria evaluation stage technique as an agro waste evaluation indicator for polymeric composites: Date palm fibers as a case study. BioResources. 2014;9(3):4608-21.

[122] Sabaei D., Erkoyuncu J. and Roy R.. A review of multi-criteria decision making methods for enhanced maintenance deliveryvol. Understanding the life cycle implications of manufacturing. 2015;37:30-35. 